\title{
What strengthens resilience in public administration institutions?
}

\author{
Alina Georgiana PROFIROIU*, Corina-Cristiana NASTACA $\breve{A}^{* *}$
}

\begin{abstract}
Public administration has to cope with the constant changes which affect today's society and continue to ensure citizens' well-being. Consequently, public institutions should strengthen their capacity to manage the unforeseen, namely, to become resilient to different types of shocks. In this context, the present research aims to investigate the concept of resilience, trying to establish the most important drivers of institutional resilience. The main objective is to propose a conceptual framework based on a meta-analysis of existing studies regarding resilience which can be used for defining and measuring the capacity factors that might influence the institutional resilience of public administration. The framework will be further used in future research. It will be applied to public institutions, at different administrative levels to reveal how prepared for future shocks they are and to find out new ways of strengthening their resilience. From the methodological point of view, an exploratory study was conducted by reviewing the literature in this field in order to establish the main drivers that might influence and strengthen institutional resilience. As a result, we proposed a conceptual framework that includes the main capacity factors of institutional resilience and a set of quantitative and qualitative indicators defining these drivers.
\end{abstract}

Keywords: institutional resilience, public institutions, conceptual framework

\section{Introduction}

Modern societies are now facing different challenges from those in the past. Consequently, the countries are focused on finding the necessary tools to cope with the constant changes and possible threats. Countries should survive and develop their ability to cope with the threat of potential shocks such as political instability, economic crises, immigration, climate change, environmental disasters,

\footnotetext{
* Alina Georgiana PROFIROIU is Professor at The Bucharest University of Economic Studies, Bucharest, Romania; e-mail: alina.profiroiu@amp.ase.ro.

** Corina-Cristiana NASTACA $\breve{A}$ is Teaching Assistant at The Bucharest University of Economic Studies, Bucharest, Romania; e-mail: corina.nastaca@amp.ase.ro.
} 
globalization, demographic changes, or terrorism. Even fast-technological development and innovation can be considered factors with a great impact on societies' normal evolution. In this respect, governments and public institutions play major roles by designing policies that should foresee the potential shocks' impact, prevent them and help nations to adapt and adjust to the constant changes and, in the end, recover and evolve after shocks' striking. As an example, the medical crisis which threatens the social and economic systems of the countries due to the coronavirus pandemic represents a major shock for multiple stakeholders, including public administration (OECD, 2020; International Monetary Fund, 2020). In reality, public institutions are facing two major shocks to which they must react simultaneously: the problems faced by the national medical systems and the economic crisis which will come afterwards. The public administration must cope with the effects of the coronavirus pandemic while adopting the necessary policies for the economies to survive after this major shock. This crisis requires flexibility and a strong capacity to adapt in a short period, so as to ensure that the impact and consequences are reduced as much as possible. More than ever, public institutions should show a high level of resilience as they must respond to the needs of the affected social groups. Public institutions must help the medical system, the vulnerable groups which present a high level of exposure in this situation, the workforce, the business environment, and also act in solidarity with other states which are in need. Even more, in times of crisis, public institutions should support all the members of society by creating online platforms for communication between institutions and citizens, provide support for the vulnerable population and protect not only the most exposed to risk but also the other citizens who can cooperate and help in managing the situation. If countries did not prepare their public institutions for the management of crises, national economies, regions, or communities would be severely affected because they do not have the necessary tools to either bounce back or to bounce forward to a new state of equilibrium.

In this context, the public administration, often characterized by rigidity, should find the necessary tools to fight against the unpredictable and absorb the constant changes and challenges. Furthermore, public institutions should adapt by embracing change and innovation and also evolve while managing to deliver qualitative services for citizens. In this regard, the public administration must strengthen its resilience, a concept that is in opposition to the traditional characteristics of public institutions.

Based on rigidity, hierarchy, procedures, formalities, and specific norms, public administration is now confronting with the challenge of changing its traditional values. It should become more flexible, adaptable and, in the end, transformational. In this manner, the public administration and its institutions will manage to become resilient and cope with all the unpredictable events affecting the social and economic environment. 
The resilience of a system is a complex concept that cannot be analyzed only from one perspective. Resilience is also a variable feature because even if a system regains its initial equilibrium or evolves to a new state, a process of change will be required in the future. The system will absorb the shock and will adapt to the new circumstances by implementing more or less substantial changes. All the components of the system and the way they respond to these changes will have an impact on the system's resilience (Bruneckiene et al., 2018).

Many studies approached resilience related to natural disasters or economies to find the best solutions for developing and strengthen the resilience of the national, regional, or even local economies as well as the best measures for preparing communities, regions, or countries to respond to natural disasters. In this regard, building a resilient public administration is a complex process that must consider the influence of all types of internal and external factors.

In strengthening economic and social resilience, institutions, whether private or public, play a major role. Public administration is certainly one of the most important factors influencing resilience at the national, regional, and local levels. Building and strengthening the public administration's resilience is a process of reform, which implies different stakeholders, from the national level to the local level. A well-functioning, modern, and adaptable public administration will have a positive impact on societies' well-being and economies' development. Therefore, the need for building and strengthening public institutions' resilience and for creating a set of indicators that will help in defining and measuring the drivers of this particular type of resilience, appeared. In addition, developing a conceptual framework including the main capacity factors which influence the institutional resilience of public administration and what defines them will help to predict public institutions' responses to future shocks.

\section{Resilience - a theoretical approach}

The concept of resilience was first used in physics and referred to the modalities in which an object or a substance would react to external forces and keep its main characteristics (Peng et al., 2017). Then, the concept was used by Holling (1973) in ecology.

A system's capacity to recover after a shock and regain its equilibrium is called resilience and can be rather considered a process than a result (Bene et al., 2014; Martin, 2012; Simmie and Martin, 2010). The term could be associated with survival, but resilience is also about what a system does after it survives a shock. It could try to reach its initial state or to evolve to a new state of equilibrium by adapting to the occurred changes. Authors (Capello et al., 2015; Eraydin, 2015; Foster, 2007; Hill et al., 2008; Lester and Nguyen, 2015; Pachauri and Reisinger, 2007; Pendall et al., 2009; Pike et al., 2010; Rose and Liao, 2005; Simmie and Martin, 2010; Swanstrom, 2008; Tongyue et al., 2014; Vale and Campanella, 2005; 
Williams et al., 2013) approached the concept from different perspectives. Therefore, the literature defines many types of resilience, such as economic, social, ecological, or engineering resilience. Despite the diversity of studies approaching resilience, a general definition or a commonly agreed approach to its measurement could not be established. The reason is that building and strengthening resilience requires a comprehensive analysis where all types of factors such as economic, social, environmental, political, or natural should be analyzed and taken into consideration.

The concept was used in relation to economies, regions, communities, institutions, individuals, natural disasters, or gender issues in fields like physics, economic sciences, psychology, or ecology. It could be studied in relation to individuals (how they surpass unforeseen personal problems, professional problems, natural disasters which affect their households), small groups (like families or teams working in private or public organizations), private or public organizations (which can be affected by budgetary cuts, understaff, economic crisis), communities, regions, nations (affected by an economic crisis, climate changes, environmental problems, economic problems, unemployment, technological and medical crises) and even ecosystems (Zhou et al., 2010; O'Brien and Wolf, 2010; Cutter et al., 2008). Due to the various factors of influence, it is difficult to find a common definition of the concept and a general index or framework which could measure all these types of resilience.

The most common definition of resilience refers to the capacity of a system to cope with the shocks from the external environment (Cai et al., 2012; Wojtowicz, 2020), and preserve its core functions. In addition, when crises or shocks strike, the system will try to use all the existing resources to develop. Most of the authors conducting resilience research referred to the ability of a system to adapt and bounce back to the initial state when an unprevented event (which can be a shock or a stressor) appeared (Klein et al., 2003). Other authors considered resilience as the capacity of a system to absorb the shock, adapt to the new circumstances, and evolve to a new state of equilibrium (Holling, 1973). At a first glance, it can be noticed that, in face of a shock, a system is considered resilient if it absorbs the shock and returns to its initial state or bounce forward to a new state of equilibrium, which involves adaptation, embracing change, and continuous development. However, even if resilience is about bouncing back or bouncing forward, in both cases, the system will need to adapt and change. In face of disruption, even if the system maintains its core functions and structures, imminent changes will occur while part of the system will be forced to adapt to the new circumstances.

Scholars from the Resilience Alliance (2010) defined the concept as a system's capacity to absorb shocks and implement changes while keeping the most important structures and functions (Gunderson, 2010). They also considered that resilience has three main features: (a) 'equilibrium' or 'stability', namely the capacity of a system to hold out against unpredicted changes and continue to preserve 
its core functions and structures (b) 'self-organization' or 'self-recovery' which imply an adaptative capacity and (c) 'innovation', namely a system's capacity to implement changes and encourage adaptive learning (Tongyue et al., 2014 in Peng et al., 2014). Other authors stood by these opinions too, affirming that resilience cannot be defined only by the capacity of absorbing a shock or by the recovery capacity because resilience implies adapting to the new reality and using innovation to recover after the shock, evolve, and thrive (Aligica and Tarko, 2014).

In a report presented by the Joint Research Center, a system is considered resilient if it reacts to shocks and changes without losing its capacity to deliver sustainable societal well-being for future generations (European Commission, 2018; Manca et al., 2017). This definition assumes that resilience is a major factor for building a sustainable future, as a resilient system will have the capacity to bounce back or forward towards sustainable development. In the mentioned study, we can observe the multi-approach of the concept. The authors considered that economic, social, and environmental resilience should be treated as a whole and not separately. Consequently, the three types of resilience were included in a system based on three factors: the assets, the engine, and the outcomes. Assets are constituted by human, natural, social, and built capitals. The outcomes are considered various indicators of well-being (health, employment, happiness, household income, satisfaction, etc.). Finally, the engine has the power of transforming these assets into outcomes, through institutions and processes. This is one of the approaches that comprise the idea of institutional resilience and recognize the importance of institutions in transforming the assets into outcomes of well-being for future generations (European Commission, 2018).

Furthermore, the report uses resilience in connection with economies and societies and presents three capacities that should help societies to develop their resilience, namely the absorptive, adaptive, and transformative capacities. The main idea is that systems should adapt their strategies to cope with disturbances depending on the shocks' intensity and persistence. In the case of small shocks with low persistence, the system should try to absorb the shock without implementing important changes. As the intensity and/ or persistence are increasing, the system should try to absorb the shock and adapt while starting to implement changes. If the intensity of the shock is high and persists for a long period, the system must become more flexible to adapt to the new conditions, and the transformative capacity must be high to perform major changes. These major changes should help the system evolve and not return to the state in which it was before the disturbance. However, these three strategies of approaching resilience might not suit all types of shocks. Consequently, policies targeting specific shocks that enclose these strategies should be designed. Also, there are no specific boundaries that should predict exactly if a system should only absorb the shock or should embrace adaptation and transformation (European Commission, 2018). 
The adaptative capacity was considered a feature of resilience by many authors (Dubbeling et al., 2009; Hopkins, 2010; Innes and Booher, 2010; Maguire and Cartwright, 2008; Newman et al., 2009; Norris et al., 2008; Tidball and Krasny, 2007). The main question is how this capacity can be defined. In a study regarding communities' resilience, this capacity was approached from four perspectives: social development, community competence, economic development, and communication (Norris et al., 2008, p. 130 in Grace and Sen, 2013). Also, Hopkins (2010) looked forward and highlighted that in building resilient communities, not only adaptation is important, but also transformation.

Like other types of resilience, institutional resilience was considered to be either the organization's capacity of bouncing back to the state of equilibrium before the crises (Balu, 2001; Dutton et al., 2002; Gittell et al., 2006; Horne, 1997; Horne and Orr, 1998; Mallak, 1998b; Robb, 2000; Rudolph and Repenning, 2002; Sutcliffe and Vogus, 2003) or of bouncing forward and managing to be even more successful than in the past (Coutu, 2002; Freeman et al., 2004; Guidimann, 2002; Jamrog et al., 2006; Layne, 2001; Lengnick-Hall and Beck, 2003, 2005; Weick, 1988; Zhang et al., 2018). Other authors considered the concept as being an organization's capacity to create the appropriate environment for its employees to build their own resilience (Ledesma, 2014). This definition introduces a very important variable for building resilient organizations, namely human resources.

For public institutions, building their resilience and also their employees' could be a very challenging mission. On the one hand, those institutions resistant to change must learn to cooperate with unforeseen situations while helping civil servants to deal with the unprevented. The literature on resilience does not offer much information regarding public institutions' resilience because the majority of the studies are focused on economic resilience and on building communities' or regions' responses to natural disasters, climate change, or other types of risks (Burnside-Lawry and Carvalho, 2013; Saliterer et al., 2017; Oloo and Omondi, 2017; Briguglio, 2016).

From the literature review, we could conclude that there is no common definition or a standard set of variables that would certainly influence resilience, but there are some common features of this concept. Even if the purpose is to measure the resilience of a country, of a region, or a community in face of economic, social, or environmental shocks, the common perspective is that these systems are resilient if they have the capacity of absorbing the shock, adapt and then transform by embracing changes at a low, medium or high level. The major problem remains to identify what kind of strategy is suitable following the type of shock the system is dealing with and its persistence in time. Another difficulty is to take into consideration all the factors that might influence the system's survival, recovery, and evolution.

Regardless of the type of resilience and nature of the shocks, the main idea is that resilience is defined by a system's response to a shock and by its capacity to 
recover by using various strategies. In the public institutions' case, these strategies must certainly be included in the national policies, and resilience must be considered a development objective. Also, a general framework for measuring institutional resilience comprising all the factors of influence should be created. This type of resilience needs specific measurement indicators to observe how prepared for future shocks the public institutions are, considering their particularities and constraints.

\section{Resilience's approaches by international organizations}

The concept of resilience is integrated into policy documents and governments are creating strategies and action plans to prepare their economies for future economic, social, or environmental shocks. The Joint Research Centre (JRC) created a framework of resilience, focusing on societal well-being. Furthermore, the JRC Science for Policy Report presented an analysis of the European Member States' resilience to the financial and economic crises, which started in 2007 (European Commission, 2018). Also, The European Commission adopted an 'Action Plan for Resilience in Crisis Prone Countries' (European Commission, 2013).

Furthermore, the idea of resilience was integrated into the main development objectives of the European countries, and in the Rome Declaration (2017), the Member States affirmed that their purpose is to "make the EU stronger and more resilient, through even greater unity and solidarity amongst us and the respect of common rules". From this declaration, it could be observed that the European Union considers that strengthening resilience depends on cooperation and solidarity between states and on their capacity to respect all the imposed rules. Therefore, it could be stated that resilience was approached as a common effort of all member states, which should cooperate.

On the other hand, in the reflection paper on Harnessing Globalization (2017), resilience was approached from the perspective of each member state. The paper suggested that member states as separate entities should "boost...resilience at home" and presented the policies which should be developed to strengthen national resilience. Strong and resilient nations might have a positive impact on the European Union's resilience as a whole. The national policies regarding education, finance, and the social field should play a major role in strengthening national economies, making them competitive, and ensuring the development of the disadvantaged categories in society. The paper suggests that having strong economies and ensuring equitable living conditions for citizens will make nations more resilient.

In the Joint Communication of the European Commission, "A Strategic Approach to Resilience in the EU's External Action" (2017), resilience was defined as a complex concept that encompasses both individuals and the whole society. The main drivers of resilience were considered the "democracy, trust in institutions and sustainable development, and the capacity to reform". The paper also presented the idea that external policies might have a major impact on the EU's resilience. It could 
be observed that, in this paper, resilience was considered to be influenced by a mix of factors as national policies, including the external ones, citizens' trust in public institutions, sustainable economic and social development, and countries' capacity to implement changes in their national systems.

Also, the G20 listed a set of principles for strengthening resilience from an economic perspective. The paper named "Note on Resilience Principles in G20 Economies", approaches five major themes: the external policies, private and public finances, the monetary policy, and the real sector. Moreover, OECD developed a resilience toolkit to help designing and implementing policies that could help strengthening local communities' resilience (OECD, 2014).

\section{Resilience and public administration}

Public administration is a sector with many peculiarities facing different disruptions, shocks, stressors, and unplanned events. Constant changes in the external environment such as climate change (Fünfgeld and McEvoy, 2012), new diseases (Leach et al., 2010), understaff, low level of funding, or insufficient resources (Lodge and Hood, 2012; Skertich et al., 2013) expose public administration to different risks. Public administration should constantly adapt and embrace change to evolve and ensure highly qualitative services for citizens and enterprises or develop policies for other sectors affected by crises. Consequently, the notion of resilience started to be studied because scholars and practitioners tried to find out how to improve the process of governance in a system characterized by complexity, constant changes, and new challenges (Wildavsky, 1988; Boin et al., 2010; Aldrich, 2012; Boin and van Eeten, 2013).

Initially, the studies regarding public administration were focused on concepts like efficiency and equity, on the best modalities of spending public funds, on delivering the best services for citizens while protecting vulnerable groups. Now, the attention is focused on strengthening public administration resilience, in other words, on making it flexible and adaptable in its response to the new challenges from the internal and external environment (Hood, 1991; Duit and Galaz, 2008). The idea is supported by other authors too, who consider the potential relation between resilience and efficiency, affirming that focusing only on efficiency will make public institutions vulnerable in front of risks (Aligica and Tarko, 2014). Therefore, the need for studying the resilience of public administration appeared and the main question remains: what is either weakening or strengthening public institutions?

Public administration is a complex environment dominated by values such as effectiveness, legitimacy, and, now, resilience. The literature reveals different opinions about the importance of these values. Some authors supported the New Public Management approach which emphasized the importance of effectiveness over resilience and legitimacy and that these values are often in conflict with one another (Hood, 1991, in Duit, 2015), while others (Duit, 2015) considered resilience 
as the dominant value, which in their opinion is more important than both effectiveness and legitimacy (Duit, 2015).

In this context, strengthening the institutional resilience of public administration should be one of the first subjects to be analyzed. Public institutions play a major role in the well-functioning of the administrative system and might have an impact on building communities' or regions' resilience. The OECD (2016) considered that "higher-quality institutions (more effective government, a greater voice and accountability, better control of corruption, etc.) benefit from both higher growth and fewer occurrences of severe recessions". This affirmation underlined the importance of public institutions and their impact on the national economies' resilience. Authors (Aligica and Tarko, 2014) affirmed that public institutions are highly important in building the resilience of both economic and social systems. Their structures and functioning influence social and economic development and help in fighting against natural disasters.

Andreas Duit (2015) emphasizes that building resilience in the public administration needs a different approach due to the bureaucratic organization on which the public systems rely now. The author presented the factors on which resilient public administration might lean on: organizing public institutions in nonhierarchical networks that cross the jurisdictions, acquiring different types of knowledge, using different sources of information, involving citizens and different types of stakeholders in the decision-making process, social learning, and experiments involving "trial-and-error policies" (Duit, 2015). It can be observed that the author suggested a different type of administrative organization which is not based on hierarchy and where public institutions create communication networks between all administrative levels, where the public opinion is involved in the decision-making process and the public authorities decide after considering the opinions of various stakeholders such as NGO's or the private sector.

Regarding the institutional resilience in public administration, other authors considered that there is no universal model or reform policy that should be implemented. On the contrary, multiple models and policies should be studied and implemented (John, 2011, in Duit, 2015). While resilience became one of the core values of the public administration, public institutions should try to be flexible and adaptable while being stable, predictable, and efficient (Selznick, 1957; Wildavsky, 1988; Wilson, 1989; March, 1991). Even if flexibility is opposite to stability, the public institutions should embrace both types of behaviors because providing services to citizens presumes the idea of routine and stability, while preparing to act in conditions of major changes or shocks requires flexibility. Even if building resilience might seem a major reform of the administrative institutions, in time, this process will generate routine, and less flexibility and changes will be needed. Furthermore, the effort of building a resilient public administration will generate long-term strategies, bureaucratic norms, procedures, which will lead to reduced flexibility (Stark, 2014). 
Also, an OECD study (2016) revealed a correlation between economic development and variables, such as government effectiveness, low corruption, political stability. These findings support the studies which concluded that wellfunctioning institutions reduce the probability of severe economic shocks (Acemoglu et al., 2003; Rodrik, 1998).

Therefore, making public institutions resilient should be a matter of interest for governments and all public stakeholders. After studying the literature which emphasized the value of resilience in public administration and considering the scarcity of studies regarding public institutions' resilience, it is important to find out the main determinants of institutional resilience in public administration.

\section{Research methodology}

In order to study public institutions' resilience, it is important to understand which are the main factors that influence and strengthen it. Considering that most of the studies identified in the literature focused on regions' or on economies' resilience, the present study aims to identify the main drivers of institutional resilience and to propose a set of quantitative and qualitative indicators defining these drivers and which might influence, develop and strengthen resilience in the public administration. The study starts from the assumption that, due to the importance of this sector for economic and social development at the national, regional, or local level, a resilient public administration will impact positively the well-functioning, development, and capacity of response to shocks of communities, regions and even of the whole country.

The main objective of the study is to provide a conceptual framework derived from the meta-analysis of existing studies regarding resilience which comprises the main drivers of institutional resilience in public administration and the indicators that define them.

The research methodology consists of an exploratory study conducted by reviewing the literature in this field to establish the most important drivers that might influence and strengthen institutional resilience, which will have a positive impact on the public administration's outcomes. As a result, a conceptual framework including the main capacity factors of institutional resilience and a set of quantitative and qualitative indicators defining these drivers are proposed.

The drivers, as well as the indicators, are grouped in a conceptual framework that could be used in future research on public institutions' resilience and their outcomes. The framework includes 11 capacity factors that can favour, influence, and strengthen institutional resilience: Innovation, knowledge and creativity capacity, Learning capacity, Forecasting, and strategic planning capacity, Adaptative capacity (flexibility) and change management, Capacity of using new technologies, Stakeholders involvement in the decision-making process and in providing services, 
Leadership and organizational management quality, Transparency, Human resources quality, Networking, and cooperation capacity, Policies and strategies effectiveness.

\section{Developing a conceptual framework of institutional resilience in public administration}

Based on the literature regarding the resilience of communities, regions, economies, and institutions, a conceptual framework has been developed in order to define the drivers that influence and strengthen institutional resilience in public administration. The framework can be used in the research aimed to investigate how prepared for future shocks public institutions are. In the context of the medical crisis created by the Covid-19 pandemic and of its economic impact, the public administration must be able to help economies to recover and be prepared to manage new medical and other types of crises that will appear. Also, the framework can be useful for discovering the strengths and weaknesses of the public institutions where it will be applied. Based on a meta-analysis of resilience studies and its drivers, a set of capacity factors that might influence institutional resilience have been identified. Also, for each capacity factor, a series of quantitative or qualitative indicators that define these factors are proposed.

Table 1. Capacity factors of Institutional Resilience

\begin{tabular}{|c|c|c|c|}
\hline $\begin{array}{l}\text { Capacity } \\
\text { Factors }\end{array}$ & & Quantitative Indicators & Qualitative Indicators \\
\hline $\begin{array}{l}\text { determining } \\
\text { institutional } \\
\text { resilience }\end{array}$ & Sources & $\begin{array}{l}\text { Defining Capacity } \\
\text { Factors }\end{array}$ & $\begin{array}{l}\text { Defining Capacity } \\
\text { Factors }\end{array}$ \\
\hline $\begin{array}{l}\text { 1. Innovation, } \\
\text { knowledge, and } \\
\text { creativity } \\
\text { capacity }\end{array}$ & $\begin{array}{l}\text { Anttiroiko et al. } \\
\text { (2014); Bakiji et al., } \\
(2013) ; \quad J u c e v i c i u s \\
\text { and Galbuogiene, } \\
\text { (2012); Bruneckiene, } \\
\text { et al., 2018; Florida } \\
(2002) ; \quad \text { Sotarauta, } \\
(2005) ; \text { Tongyue, } \\
\text { Pinyi, and Chaolin, } \\
(2014) ; \text { Hill et al. } \\
(2008) ; \text { Duit, }(2015) ; \\
\text { El Ammar and } \\
\text { Profiroiu, (2020). }\end{array}$ & $\begin{array}{l}\text { 1.1 Number of projects } \\
\text { initiated } \\
1.2 \text { Number of projects } \\
\text { implemented } \\
1.3 \text { Number of proposals } \\
\text { for management } \\
\text { improvement } \\
\text { 1.4 Number of innovative } \\
\text { methods for problem- } \\
\text { solving } \\
\text { 1.5 Share of expenditure } \\
\text { for innovative activities } \\
\text { 1.6 Innovation-based } \\
\text { development strategy }\end{array}$ & \\
\hline
\end{tabular}




\begin{tabular}{|c|c|}
\hline $\begin{array}{l}\text { 2. Learning } \\
\text { capacity }\end{array}$ & 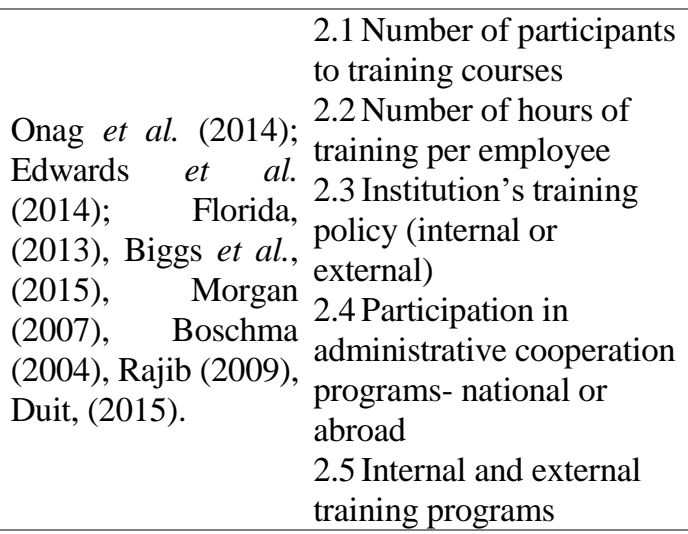 \\
\hline $\begin{array}{l}\text { 3. Forecasting } \\
\text { and strategic } \\
\text { planning capacity }\end{array}$ & 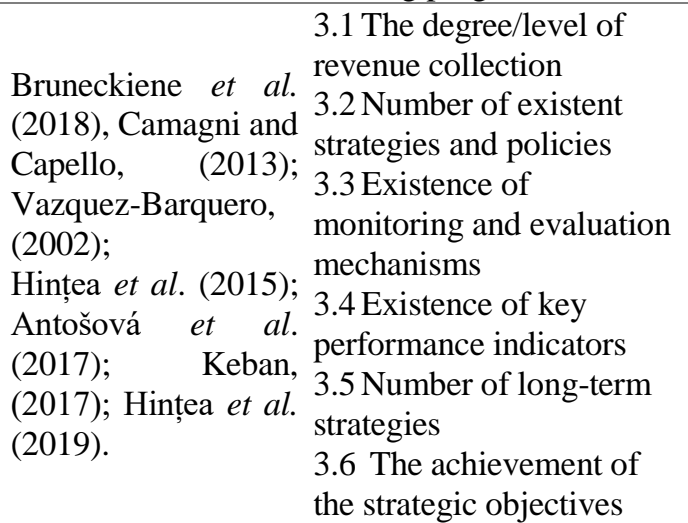 \\
\hline $\begin{array}{l}\text { 4. Adaptative } \\
\text { capacity } \\
\text { (flexibility) and } \\
\text { change } \\
\text { management }\end{array}$ & $\begin{array}{ll} & \begin{array}{l}\text { 4.1 Number of procedures } \\
\text { simplified } \\
\text { European }\end{array} \\
\text { Commission, (2018). } & \text { procedures in the total } \\
& \text { number of procedures } \\
& \text { 4.3 Number of new } \\
\text { initiatives of change } & \text { management } \\
& \end{array}$ \\
\hline $\begin{array}{l}\text { 5. The capacity of } \\
\text { using new } \\
\text { technologies }\end{array}$ & $\begin{array}{ll} & \begin{array}{l}\text { 5.1 The implementation of } \\
\text { the documents } \\
\text { management system }\end{array} \\
\text { Bruneckiene } \text { et al., } & \text { 5.2 Existence of platforms } \\
\text { (2018), the European for communication with } \\
\text { Commission (2018); citizens and enterprises } \\
\text { Fulga and Profiroiu } & \text { 5.3 Number of Digital } \\
\text { (2019); Shkarlet et } & \begin{array}{l}\text { public services provided } \\
\text { al. }(2020) .\end{array} \\
& \begin{array}{l}\text { 5.4 Existence of } \\
\text { Mechanisms for } \\
\text { implementing } \\
\text { eGovernment process }\end{array} \\
\end{array}$ \\
\hline
\end{tabular}




\begin{tabular}{|c|c|c|c|}
\hline & & $\begin{array}{l}5.5 \text { Existence of Digital } \\
\text { systems that allow the } \\
\text { exchange of information }\end{array}$ & \\
\hline $\begin{array}{l}\text { 6. Stakeholders' } \\
\text { involvement in } \\
\text { the decision- } \\
\text { making process } \\
\text { and in providing } \\
\text { services }\end{array}$ & $\begin{array}{l}\text { Östh et al., (2018) } \\
\text { Biggs et al., (2015), } \\
\text { Landau } \quad \text { (1969); } \\
\text { Wildavsky } \quad \text { (1988); } \\
\text { Comfort (1994), Duit } \\
\text { (2015). }\end{array}$ & $\begin{array}{l}6.1 \text { Number of projects } \\
\text { proposed by citizens } \\
6.2 \text { The share of public } \\
\text { spending decided by } \\
\text { participatory budgeting } \\
6.3 \text { The number of } \\
\text { participants (citizens, } \\
\text { NGOs, professional } \\
\text { associations, workers' } \\
\text { associations, } \\
\text { entrepreneurs' } \\
\text { associations) at } \\
\text { meetings/debates } \\
\text { organized by the } \\
\text { institutions. } \\
6.4 \text { Number of } \\
\text { consultations with NGO's, } \\
\text { professional associations, } \\
\text { unions, entrepreneurs } \\
6.5 \text { Number of services } \\
\text { provided in partnerships } \\
\text { with NGOs (co- } \\
\text { production) } \\
6.6 \text { Number of } \\
\text { debates/meetings with } \\
\text { citizens }\end{array}$ & \\
\hline $\begin{array}{l}\text { 7. Leadership and } \\
\text { organizational } \\
\text { management } \\
\text { quality }\end{array}$ & $\begin{array}{l}\text { Harland et al., } \\
\text { (2005); Shankar } \\
\text { Sankaran et al., } \\
\text { (2015); Luthans and } \\
\text { Avolio, (2003); } \\
\text { Kakkar, (2019), } \\
\text { T,iclău et al., (2019); } \\
\text { Andrianu (2020). }\end{array}$ & $\begin{array}{l}\text { la Number of } \\
7.1 \quad \text { per } \\
\text { brainstorming sessions per } \\
\text { month } \\
7.2 \text { Annual number of } \\
\text { turnovers in management } \\
\text { positions }\end{array}$ & $\begin{array}{l}\text { 7.3 Diversity of } \\
\text { financial and non- } \\
\text { financial motivation } \\
\text { techniques used } \\
\text { 7.4 Employees' } \\
\text { involvement in the } \\
\text { decision-making } \\
\text { process } \\
\text { 7.5 The leadership } \\
\text { styles used by } \\
\text { managers } \\
\text { 7.6 The capacity of } \\
\text { improvement of } \\
\text { personal and collective } \\
\text { competencies }\end{array}$ \\
\hline
\end{tabular}




\begin{tabular}{|c|c|c|c|}
\hline & & & $\begin{array}{l}7.7 \text { The capacity of } \\
\text { coping with political } \\
\text { instability } \\
7.8 \text { The quality of } \\
\text { communication } \\
\text { between employees } \\
\text { and leaders } \\
7.9 \text { Team-working } \\
\text { development } \\
\text { 7.10 The relationship } \\
\text { between managers and } \\
\text { employees } \\
\text { 7.11 The usage of } \\
\text { delegation for } \\
\text { appointing assignments }\end{array}$ \\
\hline 8. Transparency & $\begin{array}{l}\text { Androniceanu, } \\
(2011) \text {; European } \\
\text { Commission, (2018). }\end{array}$ & $\begin{array}{l}\text { 8.1 Reports related to } \\
\text { access to public } \\
\text { information } \\
8.2 \text { Number of public } \\
\text { information requests } \\
\text { solved in the legal time } \\
\text { and a positive manner } \\
8.3 \text { The public information } \\
\text { displayed on the } \\
\text { institutions' websites } \\
\text { 8.4 Number of investment } \\
\text { projects displayed on the } \\
\text { institutions' websites }\end{array}$ & \\
\hline $\begin{array}{l}\text { 9. Human } \\
\text { resources quality }\end{array}$ & $\begin{array}{l}\text { Sotarauta, (2005); } \\
\text { European } \\
\text { Commission, (2018); } \\
\text { Camagnir } \\
\text { Capello, and } \\
\text { Păceșilă and Colesca } \\
\text { (2019); Håkansso } \\
\text { andrakn); } \\
\text { (2020). }\end{array}$ & $\begin{array}{l}\text { Number of employees with } \\
\text { a bachelor or master degree } \\
\text { in public administration or } \\
\text { public management } \\
\text { 9.2. Existence of the } \\
\text { recruiting and promoting } \\
\text { strategy } \\
9.3 \text { Number of trained } \\
\text { employees per year } \\
\text { 9.4 Correlation between } \\
\text { employees' skills, } \\
\text { competencies, job } \\
\text { aptitudes with and } \\
\text { descriptions } \\
\text { Employees request for } \\
\text { training/ exchange } \\
\text { programs participation }\end{array}$ & \\
\hline
\end{tabular}




\begin{tabular}{|c|c|}
\hline & $\begin{array}{l}\text { Share of employees who } \\
\text { achieved their objectives in } \\
\text { total employees } \\
\text { Ratings achieved at the } \\
\text { annual evaluations } \\
\text { The existence of balanced } \\
\text { participation of men and } \\
\text { women in the total number } \\
\text { of employees } \\
\text { The existence of gender } \\
\text { policies }\end{array}$ \\
\hline $\begin{array}{l}\text { 10. Networking } \\
\text { and cooperation } \\
\text { capacity }\end{array}$ & 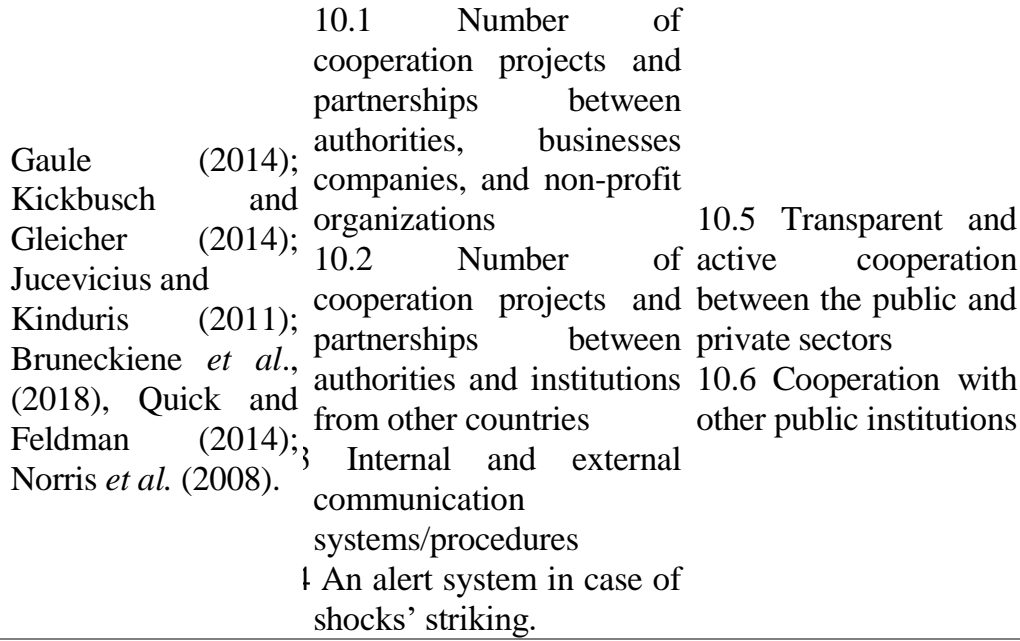 \\
\hline $\begin{array}{l}\text { 11. Policies and } \\
\text { strategies } \\
\text { effectiveness }\end{array}$ & 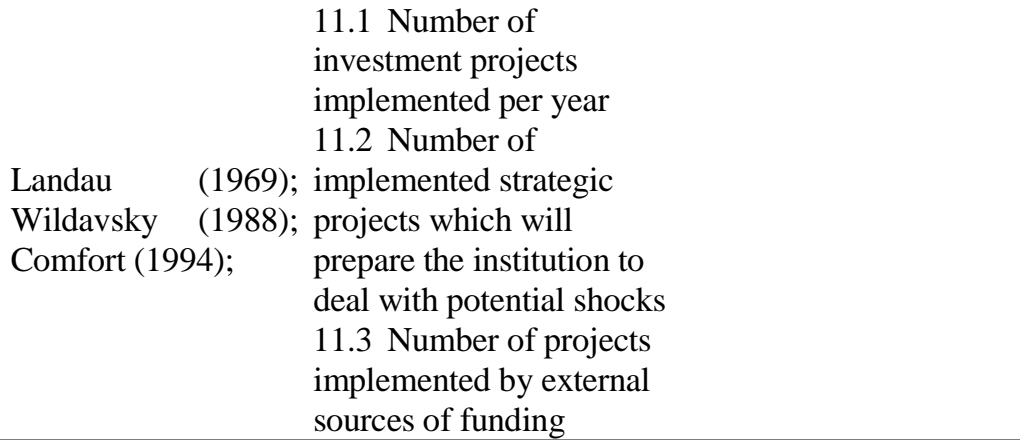 \\
\hline
\end{tabular}

Source: Authors' representation (2020)

The proposed capacity factors will impact the outcomes of public institutions' resilience which can be measured by using indicators regarding citizens' well-being and satisfaction, trust in public institutions, public services' quality, social and economic development, and good governance. 
Innovation, knowledge, and creativity capacity as well as the adaptative capacity (flexibility) and change management help at building a public administration which will be oriented to change. Implementing the management of change will make public institutions more adaptable and flexible and more prepared to cope with future shocks. More than that, they will deliver more qualitative services for its citizens, will raise their satisfaction, and their level of trust in the public institutions.

Developing the learning capacity will improve the human resources management, making them more efficient, performant, and prepared for any type of situation. Professionalized human resources will impact positively the quality of public services, will help public institutions to be more prepared for future shocks, will facilitate the transfer of know-how and consequently, trust in public institutions will rise and people will be more satisfied and eager to cooperate with these institutions.

Forecasting and strategic planning capacity and Policies and strategies effectiveness will impact positively the quality of public services and economic and social development. Public administration must be able to develop long-term strategies with an impact on the economic system. Strengthening this capacity will lead to a stronger and resilient economy, prepared to support its working force, vulnerable groups, and business environment in times of crisis and will improve governance.

The capacity of using new technologies helps public institutions to align with technological development, to improve and facilitate the relationship between public administration and its citizens, maintain functional and continuous public services in times of crisis and increase the quality of these services. Also, the use of new technologies will impact the accessibility of public services, will reduce bureaucracy, and will make public administration more efficient and performant.

Stakeholders' involvement in the decision-making process and in providing services is an important factor for good governance (Țiclău et al., 2020). Developing this capacity helps to create networks in which a diversity of knowledge, competencies, resources, and opportunities are brought together, which raises citizens' involvement in the decision-making process, leads to the implementation of collective activities and decisions that will help prevent different types of shocks and eliminate their consequences and further lead to higher satisfaction of the general interest.

Leadership and organizational management quality and human resources quality positively impact the human resources' motivation, their performances and efficiency and consequently help to improve public services' quality and to strengthen the administrative capacity.

Transparency is a capacity factor that can help to reduce corruption, raise citizens' trust in public institutions and their satisfaction, improve social and 
economic development, networking and cooperation, thus leading to qualitative public services and finally, helping institutions to be better prepared for shocks.

Strengthening all the mentioned capacity factors will make public institutions more resilient and better prepared for future shocks. In order to measure these factors, qualitative or/and quantitative indicators are provided for each of them. It should be mentioned that collecting these indicators will not be easy, as a part of them are classified as public information, some should be available from documents provided by the public institutions, while others, such as the indicators defining Leadership and organizational management quality, can be collected only by using different research tools such as questionnaires and interviews.

\section{Conclusions and future trends of research}

The present study is aimed to create a conceptual framework comprising the main drivers of institutional resilience by taking into consideration multiple determinants. As previous studies have revealed, resilience is a process that must be approached from different perspectives, including all the factors which can influence a system. Considering only an individual factor will not display complete information about the resilience of a system and its manner of reaction when facing a shock. Many studies highlighted the complex nature of this process and the various determinants which must be taken into consideration. Even if scholars and practitioners did not agree on a general definition of resilience, certainly, a resilient system must absorb the shock, adapt, and evolve. These actions imply change, which can only be implemented by adopting the necessary policies and strategies at all levels. The fact that the international forums have integrated resilience in their development objectives and strategies and the existing gap in the literature concerning the methods of strengthening public institutions' resilience designated the importance of this subject for public administration.

Public administration is a complex system where stability is no longer the main characteristic. Considering all the specific features of this field and its major impact on the well-functioning and development of a nation, public administration must be reformed in a resilient manner where change is imminent. Since public administration is a hierarchical system, the resilience of one institution influences the resilience of other institutions.

The proposed framework takes into consideration the specificities of public institutions and proposes the main factors that could define influence and strengthen institutional resilience. The framework will be further used in future research. It will be applied to public institutions, from different administrative levels, to reveal how prepared for future shocks they are and to find new ways of strengthening their resilience in front of economic, medical, cyber-security, or climate change shocks. 
Acknowledgment: This work was supported by a grant of the Ministry of Research and Innovation, CNCS - UEFISCDI, project number PN-III-P4-ID-PCCF-20160166, within the PNCDI III project "ReGrowEU - Advancing ground-breaking research in regional growth and development theories, through a resilience approach: towards a convergent, balanced and sustainable European Union”.

\section{References:}

Acemoglu, D., Johnson, S., Robinson, J. and Thaicharoen, Y. (2003), Institutional Causes, Macroeconomic Symptoms: Volatility, Crises and Growth, Journal of Monetary Economics, 50(1), pp. 49-123. https://doi.org/10.1016/S0304-3932(02)00208-8

Aldrich, D.P. (2012), Building Resilience: Social Capital in Post-Disaster Recovery, Chicago, IL: University of Chicago Press. https://doi.org/10.1111/1468-4446.12058

Aligica, P.D. and Tarko, V. (2014), Institutional resilience and economic systems: lessons from Elinor Ostrom's work, Comparative Economic Studies, 56(1), pp. 52-76. https://doi.org/10.1057/ces.2013.29

Andrianu, A.B. (2020), Resilient organizational culture: Cluj-Napoca case study, European Journal of Eastern Studies, 11(1), pp. 335-357.

Androniceanu, A. (2011), Transparency Of The Romanian Local Public Administration, Administrație și Management Public, 2011(17), pp. 33-46.

Antošová, G., Šilhánková, V. and Wokoun, R. (2017), Strategic planning in two border regions in the Czech Republic - comparison of project impact in Zlín and South Bohemia regions, Administrație şi Management Public, (29), pp.128-140.

Anttiroiko, A.V., Valkama, P., and Bailey. S.J. (2014), Smart Cities in the New Service Economy: Building Platforms for Smart Services, AI and Society, 29(3). https://doi.org/10.1007/s00146-013-0464-0

Bakiji, T., Almirall, E. and Wareham, J. (2013), A Smart City Initiative: the Case of Barcelona, Journal of Knowledge Economy, 4(2), pp. 135-148. https://doi.org/10.1007/s13132-012-0084-9

Balu, R. (2001), How to bounce back from setbacks, Fast Company, 45, pp. 148-156 (retrieved from https://www.fastcompany.com/42509/how-bounce-back-setbacks).

Bene, C., Newsham, A., Davies, M., Ulrichs, M. and Godfrey-Wood, R. (2014), Resilience, Poverty and Development, Journal of International Development, 26(5), pp. 598-623. https://doi.org/10.1002/jid.2992

Biggs, R., Schlüter, M. and Schoon. M.L. (2015), Toward principles for enhancing the resilience of ecosystem services, in: Biggs, R., Schlüter, M. and Schoon, M.L. (eds.), Principles for building resilience: sustaining ecosystem services in socialecological systems, Cambridge University Press, Cambridge, UK.

Boin, A., Comfort, L.K. and Demchack, C.C. (2010), The Rise of Resilience, in: Comfort, L.K., Boin, A. and Demchack, C.C. (eds), Designing Resilience, Pittsburgh, PA: Pittsburgh University Press, pp. 1-13. 
Boschma, R. (2004), Competitiveness of regions from an evolutionary perspective, Regional Studies, 38(9), pp. 1001-1014. https://doi.org/10.1080/0034340042000292601

Brassett, J., Croft, S. and Vaughan-Williams, N. (2013), Introduction: An Agenda for Resilience Research in Politics and International Relations, Politics, 33(4), pp. 221-228. https://doi.org/10.1111/1467-9256.12032

Briguglio, L. (2016), Exposure to external shocks and economic resilience of countries: evidence from global indicators, Journal of Economic Studies, 43(6), pp. 1057-1078. https://doi.org/10.1108/JES-12-2014-0203

Bruneckiene, J., Palekiene, O., Simanaviciene, Z. and Rapsikevicius, J. (2018), Measuring Regional Resilience to Economic Shocks by Index, Inzinerine Ekonomika-Engineering Economics, 29(4), pp. 405-418. https://doi.org/10.5755/j01.ee.29.4.18731

Burnside-Lawry, J. and Carvalho, L. (2016), A stakeholder approach to building community resilience: awareness to implementation, International Journal of Disaster Resilience in the Built Environment, 7(1), pp. 4-25. https://doi.org/10.1108/IJDRBE-07-2013-0028

Cai, J., Guo, H. and Wang, D. (2012), Review on the resilient city research overseas, Progress in Geography, 31(10), pp. 1245-1255. https://doi.org/10.11820/dlkxjz. $\underline{2012.10 .001}$

Camagni, R. and Capello, R. (2013), Regional competitiveness and territorial capital: a conceptual approach and empirical evidence from the European Union, Regional Studies, 47(9), pp. 1383-1402. https://doi.org/10.1080/00343404.2012.681640

Capello, R., Caragliu, A. and Fratesi, U. (2015), Spatial heterogeneity in the costs of the economic crisis in Europe: Are cities sources of regional resilience?, Journal of Economic Geography, 15(5), pp. 951-972. https://doi.org/10.1093/jeg/lbu053

Comfort, L.K. (1994), Risk and Resilience Interorganizational Learning Following the Northridge Earthquake, Journal of Contingencies and Crisis Management, 2(3), pp. 174 - 188. https://doi.org/10.1111/j.1468-5973.1994.tb00038.x

Coutu, D.L. (2002), How resilience works, Harvard Business Review (retrieved from https://hbr.org/2002/05/how-resilience-works).

Cutter, S.L., Barnes, L., Berry, M., Burton, C., Evans, E., Tate, E. and Webb, J. (2008), A place-based model for understanding community resilience to natural disasters, Global Environmental Change, 18(4), pp. 598-606. https://doi.org/10.1016/j.gloenvcha.2008.07.013

Dubbeling, M., Campbell, M.C., Hoekstra, F. and Veenhuizen, R. (2009), Building resilient cities, Urban Agriculture Magazine, 22, pp. 3-11 (retrieved from http://citeseerx.ist.psu.edu/viewdoc/download?doi=10.1.1.461.5301\&rep=rep1\&type= pdf).

Duit, A. and Galaz. V. (2008), Governance and Complexity: Emerging Issues for Governance Theory, Governance - An International Journal of Policy and Administration, 21(3), pp. 311-35. https://doi.org/10.1111/j.1468-0491.2008.00402.x

Duit, A. (2015), Resilience thinking: lessons for public administration: resilience thinking: lessons for public administration, Public Administration, 94(2), pp. 364-380. https://doi.org/10.1111/padm.12182 
Dutton, J.E., Frost, P.J., Worline, M.C., Lilius, J.M., and Kanov, J.M. (2002), Leading in times of trauma, Harvard Business Review, 80(1), pp. 54-61. https://doi.org/10.1177/0018726710396250

Edwards, R., Raggatt, P. and Small, N. (2014), The Learning Society: Trends and Issues, London: Routledge.

El Ammar, C. and Profiroiu, C.M. (2020), Innovation in public administration reform: a strategic reform through NPM, ICT, and e-governance. A comparative analysis between Lebanon and Romania, Administrație și Management Public, 35, pp. 75-89.

European Commission (2013), Action Plan for Resilience in Crisis Prone Countries (retrieved from https://ec.europa.eu/knowledge4policy/publication/action-planresilience-crisis-prone-countries-2013-2020_en).

European Commission (2017), A Strategic Approach to Resilience in the EU's External Action (retrieved from: https://ec.europa.eu/knowledge4policy/publication/2017-jointcommunication-strategic-approach-resilience-eus-external-action_en).

European Commission (2017), Reflection Paper on Harnessing Globalization (retrieved fromhttps://ec.europa.eu/commission/sites/beta-political/files/reflection-paperglobalisationen.pdf).

European Commission (2018), The resilience of EU Member States to the financial and economic crisis. What are the characteristics of resilient behaviour? (retrieved from https://publications.jrc.ec.europa.eu/repository/bitstream/JRC111606/jrc111606_resilie nce_crisis_pilot_withidentifiers.pdf).

Eraydin, A. (2015), Attributes and characteristics of regional resilience: Defining and measuring the resilience of Turkish regions, Regional Studies, 50(4), pp. 600-614. https://doi.org/10.1080/00343404.2015.1034672

Florida, R. (2002), The rise of the creative class: and how it's transforming work, leisure, community and everyday life, NY Basic Books, New York.

Florida, R. (2013), The learning region, in: Acs, Z.J. (ed.), Regional innovation, knowledge, and global change, 2nd ed, New York: Routledge.

Foster, K.A. (2008), Case Study Approach to Understanding Regional Resilience, Working Paper, Institute of Urban and Regional Development, University of California.

Freeman, S.F., Hirschhorn, L. and Maltz, M. (2004a), Organization resilience and moral purpose: Sandler O'Neill and partners in the aftermath of 9/11/01, Paper presented at the National Academy of Management meetings, New Orleans, LA. Freeman, S. F.

Fulga, T.M. and Profiroiu, C.M. (2019), Do Local Government Websites Meet The Minimum Criteria To Serve Their Purpose?, Management Research and Practice, 11(2), pp. 45-63.

Fünfgeld, H. and McEvoy, D. (2012), Resilience as a useful concept for climate change adaptation?, Planning Theory \& Practice, 13(2), pp. 324-28.

Gaule, E. (2014), Sumanus viesasis valdymas: samprata ir dimensijos, Public policy and administration, 13(3), pp. 372-385. http://dx.doi.org/10.5755/j01.ppaa.13.3.8300

Gittell, J.H., Cameron, K., Lim, S. and Rivas, V. (2006), Relationships, layoffs, and organizational resilience: Airline industry responses to September 11th, Journal of 
Applied Behavioral Science, 42(3), 300-330. https://doi.org/10.1177/0021886306286466

Grace, D. and Sen, B.A. (2013), Community Resilience and the Role of the Public Library, Library Trends, 61(3), pp. 513-541. http://dx.doi.org/10.1353/lib.2013.0008

Guidimann, T. (2002), From recovery to resilience, The Banker, 3-6.

Gunderson, L. (2000), Ecological resilience: In theory and application, Annual Review of $\begin{array}{llll}\text { Ecology and } \quad \text { Systematics, } & \text { 31(1), } & \text { pp. }\end{array}$ https://doi.org/10.1146/annurev.ecolsys.31.1.425

Håkansso, P.G. and Bejaković, P. (2020), Labour market resilience, bottlenecks and spatial mobility in Croatia, Eastern Journal of Eastern Studies, 11(2), pp. 5-25.

Harland, L.K., Harrison, W., Jones, J.R. and Reiter-Palmon, R. (2005), Leadership Behaviors and Subordinate Resilience, Journal of Leadership \& Organizational Studies, 11(2), pp. $2-14$.

Hill, E.W., Wial, H. and Wolman, H. (2008), Exploring Regional Resilience, Working Paper, Macarthur Foundation Research Network on Building Resilient Regions, University of California Berkeley.

Hințea, C.E., Profiroiu, M.C. and Țiclău, T.C. (2015), Strategic Planning and Public management Reform: The Case of Romania, Transylvanian Review of Administrative Science, 11(SI), pp. 30-44.

Hințea, C.E., Profiroiu, M.C. and Țiclău, T.C. (2019), Strategic Planning in Local Public Administration: The Case of Romania, in: Hintea, C. Profiroiu, M.C., Ticlau, T.C. (eds.), Strategic Planning in Local Communities. A Cross-National Study of 7 Countries, UK: Palgrave Macmillan, pp. 71-113.

Hood, C. (1991), A Public Management for All Seasons?, Public Administration, 69(1), pp. 3-19. https://doi.org/10.1111/j.1467-9299.1991.tb00779.x

Holling, C.S. (1973), Resilience and stability of ecological systems, Annual Review of Ecology and Systematics, 4(1), pp.1-23. https://doi.org/10.1146/annurev.es. $\underline{04.110173 .000245}$

Hopkins, R. (2010), What can communities do?, in: Heinberg, R. and Lerch, D. (eds.), The post carbon reader, Berkeley, CA: University of California Press.

Horne, J.F.I. (1997), The coming of age of organizational resilience, Business Forum, 22(2/3), pp. 24-28.

Horne, J.F.I. and Orr, J.E. (1998), Assessing behaviors that create resilient organizations, Employee Relations Today, 24(4), pp. 29-39. https://doi.org/10.1002/ert.3910240405

Innes, J.E. and Booher, D.E. (2010), Planning with complexity: An introduction to collaborative rationality for public policy, Abingdon, England: Routledge. https://doi.org/10.4324/9781315147949

International Monetary Fund (2020), Policies to support people during the Covid-19 pandemic. 
Jamrog, J.J., McCann, J.E.I., Lee, J.M., Morrison, C.L., Selsky, J.W. and Vickers, M. (2006), Agility and resilience in the face of continuous change, American Management Association.

John, P. (2011), Making Policy Work, Abingdon: Routledge.

Jucevičius, R. and Galbuogiene, A. (2012), The need for intelligence about business and social environment, 7th International Scientific Conference Business and Management 2012, pp. 647-654.

Jucevicius, R. and Kinduris, V. (2011), Knowledge Networks for Innovation: Motives and Benefits, Socialiniaimokslai, 4(74), pp. 63-69. https://doi.org/10.1080/ $\underline{13662710701253441}$

Kakkar, S. (2019), Leader-member exchange and employee resilience: the mediating role of regulatory focus, Management Research Review, 42(9), pp. 1062-1075.

Keban, Y.T. (2017), Risk management: a neglected vital instrument in public administration in Indonesia, Management Research and Practice, 9(4), pp. 5-21.

Kickbusch, I. and Gleicher, D. (2014), Smart Governance for Health, in: Kickbusch, I. and Gleicher, D. (eds.), Smart Governance for Health and Well-being: The Evidence, Denmark: World Health Organizations.

Klein, R., Nicholls, R. and Thomalla, F. (2003), Resilience to natural hazards: How useful is this concept?, Environmental Hazards, 5(1), pp. 35-45. https://doi.org/10.1016/j.hazards.2004.02.001

Landau, M. (1969), Redundancy, Rationality, and the Problem of Duplication and Overlap, Public Administration Review, 29(4), pp. 346-58. https://doi.org/10.2307/973247

Layne, A. (2001), How to make your company more resilient (retrieved from http://www/fastcompany.com/articles/2001/03/odwalla.html).

Leach, M., Scoones, I. and Stirling. A. (2010), Governing epidemics in an age of complexity: Narratives, politics and pathways to sustainability, Global Environmental Change, 20(3), pp. 369-77. https://doi.org/10.1016/j.gloenvcha.2009.11.008

Lengnick-Hall, C.A. and Beck, T.E. (2003), Beyond bouncing back: The concept of organizational resilience, Seattle, WA: Paper presented at the National Academy of Management meetings.

Lengnick-Hall, C.A. and Beck, T.E. (2005), Adaptive fit versus robust transformation: How organizations respond to environmental change, Journal of Management, 31(5), pp. 738757. https://doi.org/10.1177/0149206305279367

Lester, T.W. and Nguyen, M.T. (2015), The economic integration of immigrants and regional resilience, Journal of Urban Affairs, 38(1), 42-60. https://doi.org/10.1111/juaf.12205

Lodge, M. and Hood, C. (2012), Into an age of multiple austerities? Public management and public service bargains across OECD Countries, Governance, 25(1), pp. 79-101. https://doi.org/10.1111/j.1468-0491.2011.01557.x

Luthans, F. and Avolio, B. (2003), Authentic leadership: A positive development approach, in: Cameron, K.S., Dutton, J.E. and Quinn, R.E. (eds.), Positive organizational 
scholarship: Foundations of a new discipline, San Francisco, CA7 Berrett-Koehler, pp. 241-261.

Maguire, B. and Cartwright, S. (2008), Assessing a community's capacity to manage change: A resilience approach to social assessment, Australian Government Bureau of Rural Sciences. http://dx.doi.org/10.5755/j01.ppaa.13.3.8300

Mallak, L.A. (1998b), Putting organizational resilience to work, Industrial Management, 40(6), pp. 8-13.

Manca A.R., Benczur, P. and Giovannini, E. (2017), Building a Scientific Narrative Towards a More Resilient EU Society, JRC Science for Policy Report (retrieved from http://publications.jrc.ec.europa.eu/repository/bitstream/JRC106265/jrc106265_100417 _resilience_scienceforpolicyreport.pdf).

March, J.G. (1991), Exploration and Exploitation in Organizational Learning, Organization Science, 2(1), pp. 71-87.

Martin, R.L. (2012), Regional Economic Resilience, Hysteresis and Recessionary Shocks, Journal of Economic Geography, 12(1), pp. 1-32. https://doi.org/10.1093/jeg/lbr019

Morgan, K. (2007), The learning region: institutions, innovation and regional renewal. Regional Studies, 41(S1), pp. 147-159. https://doi.org/10.1080/00343409750132289

Newman, P., Beatley, T. and Boyer, H. (2009), Resilient cities: Responding to peak oil and climate change, Washington, DC: Island Press

Norris, F.H., Stevens, S.P., Pffefferbaum, B., Wyche, K.F. and Pffefferbaum, R.L. (2008), Community resilience as a metaphor, theory, set of capacities, and strategy for disaster readiness, American Journal of Community Psychology, 41(1), pp. 127-150. http://dx.doi.org/10.1007/s10464-007-9156-6

O'Brien, K. and Wolf, J. (2010), A values-based approach to vulnerability and adaptation to climate change, Wiley Interdisciplinary Reviews: Climate Change, 1(2), pp. 232-242. https://doi.org/10.1002/wcc. 30

OECD (2014), Boosting Resilience through Innovative Risk Governance, Paris: OECD Publishing. https://doi.org/10.1787/19934106

OECD (2016), Strengthening economic resilience: insights from the post-1970 record of severe recessions and financial crises, Paris: OECD Publishing (retrieved from https://www.oecd.org/economy/growth/Strengthening-economic-resilience-insightsfrom-the-post-1970-record-of-severe-recessions-and-financial-crises-policy-paperdecember-2016.pdf).

OECD (2020), The territorial impact of COVID-19: Managing the crisis across levels of government, Paris: OECD Publishing (retrieved from https://www.oecd.org/coronavirus/policy-responses/the-territorial-impact-of-covid-19managing-the-crisis-across-levels-of-government-d3e314e1/).

Oloo, J. and Omondi, P. (2017), Strengthening local institutions as avenues for climate change resilience, International Journal of Disaster Resilience in the Built Environment, 8(5), pp. 573-588. https://doi.org/10.1108/IJDRBE-12-2013-0047 
Onag, O.A., Tepeci, M. and Basalp, A.A. (2014), Organizational Learning Capability and its Impact on Firm Innovativeness (retrieved from: http://ac.elscdn.com/S1877042814050782/1 main.pdf?tid=ad61bd16-4b27 11e5897d00000aab0f6b\& acdnat=1440507128_ee607bc73774037 fa6e9729d76432200).

Östh, J., Reggiani, A. and Nijkamp, P. (2018), Resilience and accessibility of Swedish and Dutch Municipalities, Transportation, 45(4), pp. 1051-1073. https://doi.org/10.1111/rsp3.12351

Pachauri, R.K. and Reisinger A. (2007), Climate change synthesis report: Summary for policymakers, IPCC Secretariat.

Păceșilă, M. and Colesca, S.E. (2019), Professional training of Romanian civil servants in territorial administrative units, Administrație și Management Public, 33, pp. 133-146.

Pike, A., Dawley, S. and Tomaney, J. (2010), Resilience, adaptation and adaptability. Cambridge Journal of Regions, Economy and Society, 2(12), pp. 59-70. https://doi.org/10.1093/cjres/rsq001

Pendall, R., Foster, K.A. and Cowell, M. (2009), Resilience and regions: Building understanding of the metaphor, Cambridge Journal of Regions, Economy and Society, 3(1), pp. 71-84. https://doi.org/10.1093/cjres/rsp028

Peng, C., Yuan, M., Gu, C., Peng, Z. and Ming, T. (2017), A review of the theory and practice of regional resilience, Sustainable Cities and Society, 29, pp. 86-96. https://doi.org/10.1016/j.scs.2016.12.003

Rajib, S. (2009), City profile: climate and disaster resilience, United Nations University (UNU), Citynet (CITYNET), United Nations Office for Disaster Risk ReductionHyogo Liaison Office (UNISDR Hyogo), Asia Regional Task Force on Urban Risk Reduction (RTF-URR).

Quick, K.S. and Feldman. M.S. (2011), Distinguishing participation and inclusion, Journal of Planning Education and Research, 31(3), pp. 272-290. https://doi.org/10.1177/0739456X11410979

Resilience Alliance (2010), Assessing resilience in social-ecological systems: workbook for practitioners. Version 2 (retrieved from http://www.reefresilience.org/ pdf/ResilienceAssessment2.pdf).

Rodrik, D. (1998), Who needs capital-account convertibility?, Essays in International Finance, pp. 55-65.

Rose, A. and Liao, S.Y. (2005), Modeling regional economic resilience to disasters: A computable general equilibrium analysis of water service disruptions, Journal of Regional Science, 45(1), pp. 75-112. https://doi.org/10.1111/j.0022-4146.2005.00365.x

Robb, D. (2000), Building resilient organizations, OD Practitioner, 32(3), pp. 27-32 (retrieved from http://learninginaction.com/PDF/ResilientRobb.pdf)

Rudolph, J.W. and Repenning, N.P. (2002), Disaster dynamics: Understanding the role of quantity in organizational collapse, Administrative Science Quarterly, 47(1), pp. 1-30. https://doi.org/10.2307/3094889 
Saliterer, I., Jones, M. and Steccolini, I. (2017), Introduction: Governments and Crises. Governmental Financial Resilience, Public Policy and Governance, 27, pp. 1-16.

Skertich, R.L., Johnson, D.E. and Comfort, L.K. (2013), A bad time for disaster: Economic stress and disaster resilience, Administration \& Society, 45(2), pp. 145-166. https://doi.org/10.1177/0095399712451884

Selznick, P. (1957), Leadership in Administration: A Sociological Interpretation, Evanston, IL: Row, Peterson.

Shankar Sankaran, P., Rodríguez-Sánchez, A.M. and Perea, V.M. (2015), The secret of organisation success: a revision on organisational and team resilience, International Journal of Emergency Services, 4(1), pp. 27-36. http://dx.doi.org/10.1108/IJES-09$\underline{2014-0018}$

Shkarlet, S., Oliychenko, I., Dubyna, M., Ditkovska, M. and Zhovtok, V. (2020), Comparative analysis of best practices in e-Government implementation and use of this experience by developing countries, Administrație și Management Public, 34, pp. 118-136.

Simmie, J. and Martin, R. (2010), The economic resilience of regions: towards an evolutionary approach, Cambridge Journal of Regions, Economy and Society, 3(1), pp. 27-43. https://doi.org/10.1093/cjres/rsp029

Sotarauta, M. (2005), Tales of resilience from two Finnish cities: self-renewal capacity at the heart of strategic adaptation, in: Duke, C., Osborne, M., Wilson, B. (eds.), Rebalancing the social and economic learning, partnership and place, Niace, Leicester, pp. 93-105.

Stark, A. (2014), Bureaucratic Values and Resilience: An Exploration of Crisis Management Adaptation, Public Administration, 92(3), pp. 692-706. https://doi.org/10.1111/padm.12085

Sutcliffe, K.M. and Vogus, T.J. (2003), Organizing for resilience, in: Cameron, K.S., Dutton, J.E. and Quinn, R.E. (eds.), Positive organizational scholarship: Foundations of a new discipline, San Francisco: Berrett-Koehler, pp. 94-110.

Swanstrom, T. (2008), Regional resilience: A critical examination of the ecological framework, Working Paper, Institute of Urban \& Regional Development Urban and Regional Development, University of California, Berkeley.

Tidball, K.G. and Krasny, M. (2007), From risk to resilience: What role for community greening and civic ecology in cities?, in: Wals, A.E.J. (ed.), Social learning: Toward a sustainable world, Wageningen: Wageningen Academic Publishers, pp. 149-164.

Țiclău, T., Hințea, C. and Andrianu, B. (2020), Adaptive and turbulent governance. Ways of governing that foster resilience. The case of the Covid-19 pandemic, Transylvanian Review of Administrative Sciences, Special Issue, 2020, pp. 167-182. http://dx.doi.org/10.24193/tras.SI2020.10

Țiclău, T., Hințea, C. and Andrianu, B. (2019), Leadership resilient. O scurtă analiză a conceptului (eng. Resilient Leadership. A Short Theoretical Analysis of the Concept), Revista Transilvană de Științe Administrative, 2(45), pp. 63-72.

Tongyue, L., Pinyi, N. and Chaolin, G. (2014), A review on research framework of resilient cities, Urban Planning Forum, 218(5), pp. 23-31. 
Vale, L.J. and Campanella, T.J. (2005), The resilient city: How modern cities recover from disaster, Oxford University Press.

Vazquez-Barquero, A. (2002), Endogenous development, Routledge, London. https://doi.org/10.4324/9780203217313

Wojtowicz, N. (2020), Resilience against intentional shocks: a wargaming study of the relation between space, action and the residing population to resilience, Eastern Journal of European Studies, 11(1), pp. 5-26.

Weick, K.E. (1988), Enacted sensemaking in crisis situations, Journal of Management Studies, 25(4), pp. 305-317. https://doi.org/10.1111/j.1467-6486.1988.tb00039.x

Wildavsky, A. (1988), Searching for Safety. Piscataway, NJ: Transaction Publishers. https://doi.org/10.1177/027046769001000432

Williams, N., Vorley, T. and Ketikidis, P. (2013), Economic resilience and entrepreneurship: A case study of the Thessaloniki City Region, Local Economy, 3(17), pp. 399-415. https://doi.org/10.1177/0269094213475993

Wilson, J.Q. (1989), Bureaucracy: What Government Agencies Do and Why They Do It, New York: Basic Books.

Zhang, F., Welch, E.W. and Miao, Q. (2018), Public Organization Adaptation to Extreme Events: Mediating Role of Risk Perception, Journal of Public Administration Research and Theory, 28(3), pp. 371-387.

Zhou, H., Wang. J., Wan, J. and Jia, H. (2010), Resilience to natural hazards: A geographic perspective, Natural Hazards, 53(1), pp. 21-41. 